\title{
JEGO WEHRMACHT, CZYLI POLSKO-NIEMIECKA AKADEMIA JĘZYKOWA JANUSZA RUDNICKIEGO W „KSIĄŻKACH. MAGAZYNIE DO CZYTANIA"1
}

\author{
MAEGORZATA ZDUNIAK-WIKTOROWICZ² \\ (Uniwersytet im. Adama Mickiewicza w Poznaniu)
}

Słowa kluczowe: wojna, Polska, Niemcy, polszczyzna, literatura emigrancka

Keywords: war, Poland, Germany, Polish language, emigrants' literature

\begin{abstract}
Abstrakt: Małgorzata Zduniak-Wiktorowicz, JEGO WEHRMACHT, CZYLI POLSKO-NIEMIECKA AKADEMIA JĘZYKOWA JANUSZA RUDNICKIEGO W „KSIĄŻKACH. MAGAZYNIE DO CZYTANIA”, „PORÓWNANIA” 15, 2014, T. XV, s. 185-197. ISSN 1733-165X. Nową i ciekawą odsłonę walki na wyeksploatowane, ale podlegające aktualizacjom znaczenia wojenne stanowią teksty publikowane przez Janusza Rudnickiego w kwartalniku Książki. Magazyn do czytania (Agora). W autorskich omówieniach niemieckiej literatury autor oddelegowany do polskoniemieckich poruczeń wciąż na nowo artykułuje - na przykład w postaci frazemów i frazesów znane wojenne języki. Wykorzystuję je $\mathrm{w}$ artykule jako postkolonialny koncept uzupełniania przez Rudnickiego polsko-niemieckiej matrycy historycznej, ale też objaśniania uprzedzeń, stereotypów i napięć utrzymujących się w przestrzeni sąsiedzkiej komunikacji.
\end{abstract}

\begin{abstract}
Małgorzata Zduniak-Wiktorowicz, HIS WEHRMACHT OR POLISH-GERMAN LANGUAGE ACADEMY BY JANUSZ RUDNICKI IN „KSIĄŻKI. MAGAZYN DO CZYTANIA” [„BOOKS. A MAGAZINE TO READ”]. “PORÓWNANIA” 15, 2014, Vol. XV, p. 185-197. ISSN $1733=165 X$. The texts published by Janusz Rudnicki in the quarterly Ksiażki. Magazyn do czytania (Agora) present a new and interesting scene of fighting with the use of the exploited but still constantly updated meanings of war. In the author's discussions of German literature, the writer, delegated to Polish-German commissions, continually articulates - for instance in the form of phrasemes and phrases - well-known war languages. I use them in the paper as a post-colonial
\end{abstract}

\footnotetext{
${ }^{1}$ Eseistyczno-biograficzne teksty Janusza Rudnickiego, które omawiam w tym artykule, już po jego napisaniu ukazały się w najnowszej książce autora Życiorysta. Warszawa 2014.

2 Correspondence Address: mzduniak@amu.edu.pl
} 
concept of Rudnicki's supplementation of the Polish-German historical matrix, but also as explanation of the prejudice, stereotypes and tensions persisting in the space of neighborhood communication.

\section{PRAJĘZYK}

Języki literackiej postkolonialności mają w najnowszej polskiej prozie różne natężenie; mogą przyjmować postać ściszonej, wstydliwej sugestii bycia ofiarą, ale bywa też, że brzmią bardzo wyraźnie. Dzieje się tak na przykład, gdy ich tkankę tworzą doświadczenia, a więc również słowa znane z historii najnowszej i jej ciągów dalszych, które sięgają teraźniejszości. Bardzo donośny wariant takiego języka wybiera w swej najnowszej powieści Ignacy Karpowicz:

Już niedługo wojna się skończy. [...] Zabiorę cię do mojej matki, ma piękną willę pod niemieckim miasteczkiem Haradok. [...] Potem weźmiemy ślub. Będziesz czasem gotować polnische jedzenie. Wszystkim posmakuje. Będziemy mieli pięcioro dzieci: Waschil, Griken, Jan, Phrosch, Schiessen. Będziemy jeździć do kurortów i nad morze (morze to po niemiecku Juden). Będziemy mieli kota o imieniu Raus. Kot będzie się wygrzewać w słońcu i łowić Schweine (to po niemiecku myszy). Sąsiad, starszy elegancki pan w garniturze $\mathrm{w}$ prążki, Herr Abramowitsch, zapisze nam swój majątek. A inny sąsiad też z Polen, pan Buchwald, wyda swoją córkę za naszego pierworodnego ${ }^{3}$.

Sońka jest pełna polsko-niemieckiego idiomu, tego języka, który siedemdziesiąt lat po wojnie wciąż jest ostry i dźwięczny. Dlatego też nie wymaga objaśnień, jeśli chodzi o jego pokrętną, lecz w gruncie rzeczy bardzo czytelną leksykę i składnię. Czasownik „strzelać" jako antroponim, czy toponim „Buchwald” w funkcji nazwiska przyszłego żydowskiego sąsiada z Polski udowadniają, że tym, co zostaje, są wspomnienia oraz język. I to nim po latach rekonstruuje się tu oba równoległe plany wydarzeń: wojnę i miłość.

Wszystkie te zabiegi składają się na tkankę semantycznych i bardzo przenikliwych medytacji4; z jednej strony oskarżają wojnę o miłosny dramat chłopki z Podlasia i niemieckiego oficera, z drugiej - celnie wydobywają to, co można nazwać polsko-niemieckimi artykulacjami doświadczenia wojennego. Pisarz pokazuje, że "raus", „Polen” i „Juden”, umieszczone w swej bezpośredniej bliskości, to wyrazy intuicyjnie zrozumiałe. Obywają się bez dookreślania, mimo że wbrew prawidłom semantyki językoznawczej niemiecka leksyka czytana jest tu z perspektywy użyt-

${ }^{3}$ I. Karpowicz, Sońka. Kraków 2014, s. 56. Cytowany fragment ukazał się wcześniej w prasie: I. Karpowicz, Dawno, dawno temu, w najmniej odpowiednim momencie. "Gazeta Wyborcza. Magazyn", 26-27 kwietnia 2014, s. 25.

${ }^{4}$ Por. A. Wierzbicka, Kocha, lubi, szanuje. Medytacje semantyczne. Warszawa 1971. 
kownika polszczyzny. Widzimy więc, że słowa - kulturowe artefakty danego społeczeństwa - jak pisze Anna Wierzbicka, to również

swego rodzaju narzędzia pojęciowe, w których zakodowane jest przeszłe doświadczenie społeczeństwa, odnoszące się zarówno do sfery działania, jak i charakterystycznego dla niego sposobu myślenia. Narzędzia te służą także utrwalaniu tych doświadczeń. Jednak w miarę, jak społeczeństwo się zmienia, również i one mogą podlegać stopniowym zmianom, aż w końcu mogą się zupełnie zdezaktualizować. $W$ tym sensie nie można powiedzieć, by światopogląd danej społeczności był całkowicie zdeterminowany przez określony zestaw narzędzi pojęciowych, którymi ona dysponuje, ale z pewnością pozostaje pod silnym ich wpływem 5 .

Karpowicz w Sońce powtarza sprawdzone literacko znaczenia, które kodują doświadczenie nazistowskiej okupacji w Polsce, ale jednocześnie je przekracza, istotnie rekonstruując. Robi to bowiem z miejsca, które jest dla niego artystycznie bardzo ważne, z pogranicznego Podlasia - dziś polskiego, gdzie sam mieszka, ale wcześniej białoruskiego. Dlatego jego postaci skarżą się na wojnę iście postkolonialnym językiem, który podkreśla jednoczesne wykluczenie i przemoc, jaką i tak przyjdzie za nie zapłacić:

A był to czas wielu wojen, z których żadna nie była naszą. Palaki biły się z Niemcami i Ruskimi, teraz Ruscy z Niemcami, na jednak niezbyt to dotykało, bo my nie ichnie, my niczyje, my samoswoje [...]. Koniec świata ma to do siebie, że wojna dociera tam rzadko [...]; jeśli jednak już dociera, to w przerażającej postaci. Dopiero później mieliśmy tego doświadczyć6.

Kompozycja utworu podkreślająca i fatalizm uwikłania mieszkańców białoruskich wsi w „nie ich wojnę”, i siłę polsko-niemieckich języków doświadczenia, które wchłaniają doświadczanie mniejszości, wymaga jednak bliższego przestudiowania $\mathrm{w}$ innym miejscu. Teraz warto spojrzeć na to, jak poważne polityczne obowiązki nałożono na Sońkę już tydzień po jej ukazaniu się. Ryszard Koziołek napisał:

KOCHAJĄA SOŃKA REALIZUJE ŻARLIWIE POLITYKE POJEDNANIA, DŁUGO PRZED TYM, ZANIM BISKUPI POLSCY NAPISZĄ DO BISKUPÓW NIEMIECKICH, ŻE PRZEBACZAJĄ I PROSZĄ O PRZEBACZENIE (sic!).

Odniesienie do Orędzia biskupów polskich do ich niemieckich braci w Chrystusowym urzędzie pasterskim z 1965 roku przywodzi na myśl inne późniejsze, a dzięki swej teatralizacji bardziej medialne obrazy z powojennych stosunków polsko-niemieckich. Uklęknięcie Willy'ego Brandta przed warszawskim pomnikiem Bohaterów

${ }^{5}$ Ibidem, s. 23.

${ }^{6}$ I. Karpowicz, op. cit., s. 28-29.

7 R. Koziołek, Esesman, mój bliźni. „Książki. Magazyn do czytania” 2014, nr 2, s. 9 (zapis majuskułą zapewne pochodzi od redakcji) i 11. 
Getta, spotkanie oraz uścisk Tadeusza Mazowieckiego i Helmuta Kohla w Krzyżowej to również swego rodzaju symboliczne hasła rozpoznawcze obchodzenia się ze stanem postkolonialności przez sprawców i ofiary wojny. Jak jednak w swej książce Wina narodów przypomina Karolina Wigura, Kniefall czynił adresatami tego milczącego gestu Brandta nie Polaków a Żydów. W kontekście języków postkolonialności z pewnością warto więc pamiętać o błędnych, zdaniem badaczki, interpretacjach uklęknięcia jako „pojednania ze Wschodem"

Sońka reklamowana jest na okładce „Książek. Magazynu do czytania” jako podobny gest, powieść, która zmienia historię, chce i może pojednać narody. I chociaż Koziołek w roli recenzenta sugeruje, że on sam nie wybacza i ma prawo do odmowy ${ }^{9}$, widać wyraźnie, że ilekroć na polskim horyzoncie najnowszej prozy pojawia się Niemiec jako postać literacka, to modalna rama pojednania wraca. Może to dowodzić faktu, iż kiczowato brzmiąca, powtarzana przez polityków „normalizacja historycznie naznaczonych stosunków” oraz wyeksploatowana metafora "budowania mostów” wciąż stanowią wyzwanie - i dla literatury, i literaturoznawstwa.

Nie sądzę bowiem, żeby - jak sugestywnie skądinąd pisał Dariusz Nowacki nowa polska proza odwołująca się fabularnie do Niemiec i Niemców świadczyła w początkach XXI wieku o przepracowaniu wojennej traumy i wynikających z niej kompleksów ${ }^{10}$. Tak, owszem, pojednanie w literaturze zachodziło i zachodzi, ale pod warunkiem, że wojna też się w niej pojawia. Porozumienie? Zgoda, ale tylko w bezpośrednim otoczeniu przywoływanych przez autorów: faktów, dat, liczb, czyli tych znaczących elementów, które składają się na przekazy o niej, jej nośne i wizualne języki.

\section{JĘZYK}

Języki te rozumiem jako uspołecznione sposoby wyrażania w polszczyźnie doświadczenia wojennego sensu largo, w tym oczywiście rozliczenia sposobów tematyzowania wojennych doświadczeń, wskazywanie na bariery $\mathrm{w}$ komunikacji o wojnie, czy wreszcie punktowanie przemilczeń jej wybranych „momentów” i wypełnianie białych plam ${ }^{11}$. Jednak oprócz odtwarzania dobrze lub mniej zna-

8 K. Wigura, Wina narodów. Przebaczenie jako strategia prowadzenia polityki. Gdańsk-Warszawa 2011, s. 87.

${ }^{9}$ R. Koziołek, op. cit., s. 11: „Czystość literatury tkwi w tym, że przemoc słów i obrazów, zniewalająca atrakcja narracji i metafory, nie naruszają mojego prawa do odmowy”.

${ }^{10}$ D. Nowacki, O polsko-niemieckim pojednaniu (w literaturze). W: Literatura i konflikty. Red. P. Czapliński, Z. Przychodniak, P. Śliwiński. „Poznańskie Studia Polonistyczne” 2003, t. 10.

11 Piszę o tym szerzej w: M. Zduniak-Wiktorowicz, "Obrachunek” z II wojna światowa w prozie polskich pisarzy w Niemczech. W: Między językami, kulturami, literaturami. Polska literatura (e)migracyjna 
nych faktów historycznych język stwarza też, jednocześnie je notując, nowe interesujące zjawiska, które współtworzy utrzymująca się postkolonialność w stosunkach polsko-niemieckich. Tkanka polszczyzny wchodzącej $\mathrm{w}$ bliskie kontakty z niemieckością i niemczyzną bywa w tym względzie czułym sensorem. Spośród wielu tekstów literackich ${ }^{12}$ zwarty korpus nowej prozy, która te zagadnienia regularnie i na nowo tematyzuje, stanowi najnowsza twórczość emigrancka związana Niemcami jako miejscem jej powstawania. Tu właśnie odbywają się nadal potyczki z niemieckością pod postacią wciąż przywoływanej II wojny światowej. Dobitny przykład żywotności tych zagadnień, a tym samym atrakcyjności języka postkolonialności stanowi twórczość Janusza Rudnickiego.

Autor Mojego Wehrmachtu regularnie krytykuje tych, którzy chcą w nim widzieć emigranta. Upór pisarza można zrozumieć, jeśli potraktuje się to jako przejaw wyczulenia na strategie komunikacji, co jest u Rudnickiego ważnym, nasilającym się z latami elementem opisywania siebie. Oto $\mathrm{w}$ ostatnim $\mathrm{z}$ takich sprostowań, na które nigdy nie szkoda mu energii, pisarz symbolicznie przelewa krew za nieemigrację:

Jedno z pytań prowadzącej [spotkanie autorskie w ramach festiwalu Transgresje - dop. MZW] dotyczyło emigracji, coś w rodzaju, jaka jest moja i Grażyny [Plebanek - dop. MZW], kondycja jako emigrantów. Mówię, że w środę uciąłem się w palec, krojąc ser w Hamburgu, w czwartek krwawiłem w Zurychu, w piątek w Lichtensteinie, ale mniej, w sobotę jeszcze mniej, dziś wcale, a jutro, w poniedziałek, w Hamburgu zacznie się palec goić, a we wtorek będę już w Polsce i w Polsce opatrunek wyrzucę, i będzie po wszystkim. Tę historię jednego plastra dedykuję tym wszystkim, którzy ciągle jeszcze nakładają chomąto emigranta tym wszystkim, którzy pomieszkują za granicą ${ }^{13}$.

Formuła emigracyjna $\mathrm{w}$ polskiej prozie najnowszej rzeczywiście zaczęła się ostatnio szybciej starzeć14, jakby teraz wreszcie nadrabiała zadekretowane niegdyś rozstanie z emigracją pod postacią motywów czy też znanych typów postaci literackich. Bardzo wymowne jest w tym kontekście stwierdzenie Przemysława Czaplińskiego otwierające nowy zbiorowy tom analiz w całości poświęcony prozie emigrantów z lat 80., do którego pokolenia należy Janusz Rudnicki. Twierdzi badacz: „[...] ostatnia fala emigracyjna w literaturze polskiej stała się pierwszą falą migracyjną"15 i tym samym akcentuje wymuszoną upływem czasu i makroproce-

w Berlinie i Sztokholmie po roku 1981. Red. E. Teodorowicz-Hellman, J. Gesche, współpraca M. Brandt. Sztokholm 2013, s. 120-131.

12 Zob. P. Czapliński, Kompleks niemiecki w literaturze polskiej. W: Polacy - Niemcy. Literatura i pamięć. Red. J. Kałążny, J. Fiećko, S. Piontek. Poznań 2010, s. 83-128.

13 J. Rudnicki, Nóż, krew i suka. "Gazeta Wyborcza. Magazyn”, 24-25 maja 2014, s. 26.

${ }_{14}$ Zob. m.in. M. Dąbrowski, Międzytekst. Literatura między kulturami narodowymi. „Porównania” 2013, nr 13, s. 93-105.

${ }^{15}$ P. Czapliński, Kontury mobilności. W: Poetyka migracji. Doświadczenie granic w literaturze polskiej przełomu XX i XXI wieku. Red. P. Czapliński, R. Makarska, M. Tomczok, Katowice 2013, s. 8. 
sami społecznymi zmianę paradygmatu. Dodajmy w tym miejscu jednak, że w przypadku Rudnickiego emigrowanie - reemigrowanie - migrowanie, chronologia przemieszczeń pisarza, powoduje, iż to raczej wciąż związane $\mathrm{z}$ emigracją a nie migracją, $\mathrm{z}$ gruntu nierówne funkcjonowanie $\mathrm{w}$ obu kodach kulturowych, lata praktykowania przez jego odautorskich bohaterów emigracyjnej gorszości, upokorzeń, a w najlepszym razie - nieporozumień, wpływają na to, o czym pisze w zasadzie od pierwszego tomu prozy Można żyć z 1992 roku.

Interesujący mnie język, którym autor odtwarza swoje doświadczenia w polskości i niemieckości, ujawnia ponadto wieloletnie i pogłębione terminowanie jego narratora i protagonistów na semantycznej obczyźnie. Jej źródłem jest emigracja i to ona sprzyja podtrzymywaniu i rozrabianiu znaczeń charakterystycznych dla doświadczenia polskiego. Wspomaga też jednak poszerzanie naszych języków artykulacji historii XX wieku o doświadczenia niemieckie. Doskonale obrazuje to równoległość motywu wykorzystywanego przez autora Listów z Hamburga: stosy ofiar Powstania Warszawskiego zestawia i tym samym porównuje z kilometrami ciał cywilnych ofiar bombardowań w Hamburgu ${ }^{16}$.

Brygida Helbig-Mischewski, pisarka emigrancka i jednocześnie badaczka tej twórczości, również chętnie korzystająca z procesualnych jej ujęć, uważa, że pisarz-migrant to taka figura, która „ma szansę stać się ekspertem komunikacji międzykulturowej i porozumienia bez przemocy"17. Żeby tak się stało, autorzy powinni jednak „radzić sobie z innością bez nienawiści i lęku, w sposób jej niedeprecjonujący, niewykluczający czy pacyfikujący, [...] z drugiej strony - uniknąć banalizacji i tzw. kiczu pojednania [...]"18. Helbig-Mischewski jest dość wymagająca w tym względzie. Zdecydowanie skromniejsze oczekiwania miała chyba kapituła polsko-niemieckiej nagrody im. Samuela Bogumiła Lindego, którą Janusz Rudnicki odebrał w lipcu 2014 roku. Oto prozaik, który stosując techniki deprecjonująco-pacyfikujące, od dawna wykpiwał w swej prozie zadane mu tożsamości (takie jak: Polak, kandydat na Niemca, męski mężczyzna, emigrant, katolik, a więc „wszystkie te niosące przemoc dyskursy: martyrologiczny, nacjonalistyczny, [...], seksistowski, rasistowski"19) otrzymał wreszcie po latach pretendowania do rozmaitych nagród to bilateralne wyróżnienie. Jest ono według fundatorów

elementem więzi partnerskich, elementem porozumienia i pojednania, wreszcie przywołaniem i potwierdzeniem tego, co wspólne i niepodzielne, co łączy Polaków i Niem-

16 Zob. J. Rudnicki, Chodźcie, idziemy. Warszawa 2007, s. 169 oraz Śmierć czeskiego psa. Warszawa 2009, s. 24.

17 B. Helbig-Mischewski, Penis w opałach. Doświadczenia kastracji i strategie odzyskiwania mocy z literaturze kilku migrantów polskich w Niemczech. „Teksty Drugie” 2009, nr 6, s. 162.

${ }^{18}$ Ibidem, s. 163.

${ }^{19}$ H. Gosk, "Kto ty jesteś? Polak maty..." Transformacja znaczenia pojęć: „obcy”, „ojczyzna” w prozie polskiej po 1989 roku. „Porównania” 2013, nr 13, s. 113. 
ców zarówno w tym, co konkretne i lokalne, jak i w tym, co uniwersalne i nieogarnione, co łączy we wspólnej rozmowie i twórczej refleksji ludzi, społeczeństwa i narody ${ }^{20}$.

Zatem emigracja, dzięki której, powtórzmy, Rudnicki pisał to, co pisał i co powiela, dopada go jako nareszcie krajowego pisarza. Nagroda okazała się więc w odniesieniu do tej twórczości, która zatacza tu jakieś symboliczne koło, „nie tylko częścią procesu historycznego, lecz także jednym z najsilniejszych czynników sprawczych"21. Z jednej strony - nie byłoby wyróżnienia, gdyby nie latami reaktywowana przezeń pisarsko zależność i postzależność polsko-niemiecka. Z drugiej zaś - to znikanie emigracji i jej komunikacyjnych aktywów umożliwiło Rudnickiemu symboliczne odzyskanie mocy 22 w kontekście dla tego pisarza naturalnym, bo właśnie międzykulturowym, a od teraz także oficjalnie międzypaństwowym.

\section{MIĘDZYJĘZYK?}

Tymczasem w jego tekstach nie ma mowy o politycznej poprawności, o którą zabiegają liczni praktycy pojednania w duchu sąsiedztwa, które zobowiązuje. Jest za to odpalanie fajerwerków, wręcz strzelanie „mięsem armatnim” w Niemców, Polaków i w nasze komunikacyjne klisze. Świadomość międzykulturowa to bowiem, jak pisze Hanna Schreiber, nowy paradygmat prowadzenia operacji wojskowych, klucz do zwycięstwa ${ }^{23}$. Tę właśnie wiedzę i odpowiednie techniki stosuje Rudnicki, a by być bardziej wiarygodnym, jako postkolonialne, wciąż wojennie nacechowane tworzywo językowe traktuje też siebie: „'R' jak Ribbentrop, ' $u$ ' jak Mołotow, 'd' jak Deutschland" 24. Drobną alfabetyczną niezgodność można tutaj usprawiedliwić: mimo że "Mołotow” nie zaczyna się na ' $u$ ', musi towarzyszyć „Ribbentropowi”, bo w polszczyźnie oba nazwiska na trwałe zrosły się w nazwie słynnego paktu.

Oprócz licznych, rozsianych po tomach prozy, przykładów tego typu językowych zaczepek bilateralne rewindykacje autora możemy w ostatnim czasie śledzić na łamach wydawanego przez Agorę kwartalnika „Książki. Magazyn do czytania". Z tej mainstreamowej pozycji ${ }^{25}$ objaśniania on tyleż wspólne, co osobne są-

\footnotetext{
${ }^{20}$ http://www.torun.pl/pl/miasto/samorzad/miejskie-nagrody-i-wyroznienia/nagroda-im-sa muela-bogumila-lindego (data dostępu: 31.07.2014)

${ }^{21}$ P. Czapliński, Gry w prestiż. Przedmowa. W: J. F. English, Ekonomia prestiżu. Przeł. P. Czapliński, Ł. Zaremba. Warszawa 2013, s. 7.

22 Ibidem, s. 18.

${ }^{23} \mathrm{H}$. Schreiber, Świadomość międzykulturowa. Od militaryzacji antropologii do antropologizacji wojska. Warszawa 2013, s. 14.

24 J. Rudnicki, Herr Rudniki idzie za daleko. W: Trzy razy tak!. Warszawa 2013, s. 96.

${ }^{25} \mathrm{Na}$ temat rosnącej w ostatnim czasie popularności pisarza zob. M. Zduniak-Wiktorowicz, Buchstabieren Sie bitte. „OderÜbersetzen. Deutsch-Polnisches Übersetzungsjahrbuch - Karl Dedecius Archiv. Polsko-niemiecki rocznik translatorski - Archiwum Karla Dedeciusa" 2013, nr 4, s. 178-181.
} 
siedzkie znaczenia, symbole, ale też uprzedzenia, stereotypy i utrzymujące się napięcia. Redakcja czasopisma oddelegowuje go do niemiecko-polskich spraw, na jakiś zwiad lub nawet front. Trzeba przyznać, że prozaik ma w tym trudnym terenie doskonałe rozeznanie i stąd zapewne bierze się jego specyficzna tekstowa militaryzacja.

Publikując kolejne omówienia popularnej i biograficznej literatury niemieckiej26, bezpośrednio nawiązuje do swych poprzednich utworów, gdzie w bardzo zbliżony sposób analizował dzieła Nałkowskiej, Schulza czy Kafki. Jednak taka strategia pisarza, który czyta i pisze o tym, że czyta i pisze, to skądinąd również obserwowalna w twórczości mężczyzn emigrantów strategia odzyskiwania mocy, której pozbawił ich wyjazd z kraju ${ }^{27}$. Sprawdzona metoda podlega tu również reanimacji dlatego, że Rudnicki bezbłędnie wyczuwa panujący dziś popyt na biograficzność. Chodzi też przecież o to, żeby teksty się przyjmowały i sprzedawały, krzewiąc przy tym, zgodnie z zamysłem periodyku, kulturę czytania.

Jakie zatem biografie niemieckie interesują Janusza Rudnickiego? Znajdziemy wśród nich: życie i ogromne cierpienie żony kanclerza - Hennelore Kohl, biografię Josefa Ratzingera, jak ją widzi jego brat ksiądz, dzieje rodu potentatów stalowych Kruppów, biograficzne sploty Ryszarda Wagnera oraz, last but not least, życiowe oraz „literackie” dokonania Adolfa Hitlera. To właśnie oni między innymi tworzą podręczną i poręczną armię, zbiór znanych postaci, których życiorysy i ich odpowiednia lektura pozwalają autorowi pokazać, jak w Polsce i w Niemczech wraca się do znaczeń okołowojennych. Autor Śmierci czeskiego psa przekonuje przy tym, że w gruncie rzeczy bardzo często chodzi tu o język.

\section{„STYL TEJ KSIĄŻKI ROZMOWY BARWNY JEST JAK SMAK HOSTII"28}

Z tekstu Jak zostać papieżem opartego na lekturze biografii Josefa Ratzingera ${ }^{29}$ płyną liczne pożytki. Czytelnik zainteresowany polsko-niemiecką tematyką dowie się na przykład, czym jest wojna, a na przykładzie życia braci z Marktl pozna jej ożywczą moc:

Wojna, nareszcie stosunkowo mniej Kościoła. W 1942 r. do Wehrmachtu wcielony zostaje Georg, później jego jednostka zostaje przerzucona do Włoch (II wojna światowa to

\footnotetext{
${ }^{26}$ Oprócz literatury popularnej komentuje też biografie pisarzy, np. Franza Kafki, Martina Walsera czy Grimmów.

27 Por. B. Helbig-Mischewski, op. cit.

${ }^{28}$ J. Rudnicki, Jak zostać papieżem. „Książki. Magazyn do czytania” 2012, nr 1, s. 37.

${ }^{29}$ G. Ratzinger, Mój brat, Papież. Spisał M. Hesemann. Przeł. K. Markiewicz, Kraków 2012.
} 
taki okres, w którym Niemcy poznają Europę i trochę świata). Do Włoch więc, tam gdzie kwiaty piły polską krew ${ }^{30}$.

Iście polskim refleksem niemieckiej wojny, która w rodzinne strony Ratzingerów dotarła z kilkuletnim opóźnieniem, czym uatrakcyjniła, nudne, spędzane między kościołem a domowym klęcznikiem życie braci, jest wariacja Rudnickiego na temat czerwonych maków spod Monte Cassino. Oto okazuje się, że pewne skojarzenia (Włochy - kwiaty i krew) mają niezbywalny charakter, tkwią płytko pod wierzchnią narracji i cisną się na język, jeśli je tylko pomyśleć.

Osobny kontekst dla ironicznych opisów życia przyszłego papieża, który również założył niemiecki mundur, stanowi fakt, iż dla niektórych katolików w Polsce pewnym problemem na początku pontyfikatu była narodowość następcy Jana Pawła II, papieża Polaka. Tekst o Ratzingerze powstaje więc na przecięciu linii demarkacyjnych, na które składają się krajowe powinności pisarza, by polskim językiem podskórnie przekazać polską prawdę o niemieckim podboju, w którym papież prawie wziął udział, a jednocześnie zdać relację z tego, jakie miejsce zajmuje wojna w tej konkretnej niemieckiej biografii („Próbowano zmusić go do wstąpienia [do SS], powiedział to samo, chce zostać księdzem, zwymyślano go, ale udało się, nie wstąpił" ${ }^{31}$ ). Co ciekawe, rysując perspektywę Innego, autor rzadko wychodzi poza polszczyznę jako tworzywo narracji postkolonialności. W tym sensie operacjonalizacja rodzimej kultury obliczona jest na efekt pisarskiej misji - obnażenie przeciwnika. Nie wyklucza to jednak potrzeby rozumienia wroga i pokazania jego inności ${ }^{32}$. Otwartym pozostawmy pytanie, czy tym nieprzyjacielem jest tylko Niemiec. Dzięki szeroko zakrojonej ironicznej strategii pisarza łatwo bowiem domyślić się istnienia jakiegoś większego „subtekstu, którego pełne uwidocznienie z różnych względów nie jest już/jeszcze możliwe" 33 .

\section{„PRZEZ MEIN KAMPF PRZESZEDLEM JAK KULA, ZNAM NA WYLOT"34}

Ów subtekst dużo bardziej widoczny jest w eseju poświęconym dziełu Hitlera, tak jakby przy tej lekturze Rudnicki czuł większą swobodę narracyjnych ruchów. Punktem wyjścia jest tu dyskutowana w Niemczech i w Polsce zapowiedź rychłej reedycji dzieła życia Führera. Żeby dokładnie pokazać, co o tym myśli i z czym mu

\footnotetext{
30 J. Rudnicki, op. cit., s. 38.

31 Ibidem.

32 Korzystam tu z obserwacji w: H. Schreiber, op. cit., s. 23-24.

${ }^{33}$ H. Gosk, Opowieści "skolonizowanego/kolonizatora”. W kręgu studiów postzależnościowych nad literatura polska XX i XXI wieku. Kraków 2010, s. 106

34 J. Rudnicki, Drogi panie Hitler!. „Książki. Magazyn do czytania” 2012, nr 3, s. 41.
} 
się rzecz kojarzy, prozaik tworzy w swym imponującym wyobraźnią tekście dokładny scenariusz czytania Mein Kampf. Oto w środku sezonu wybrał się z książką nad polskie morze, $\mathrm{w}$ nieprzypadkowe $\mathrm{z}$ uwagi na historię miejsce:

Czas: koniec sierpnia 2012. Miejsce: Kołobrzeg, plaża. Osoby: ja jako jedyny z książką pod pachą oraz tłum. Książka: „Mein Kampf”. Autor: znany, ja: mniej. O wolne miejsce: trudno. Ludzie: jak w wagonach towarowych. Powietrze: jak $w$ wagonach towarowych. O? Co z boku słyszę? Słyszę: stój, bo zginiesz! Ja? Nie, to nie do mnie, to matka do dziecka.

Wrażenie: jak pole minowe ${ }^{35}$.

Odniesienia do politycznie poprawnych dyskursów, m.in. antysemickiego, pojawiają się w tekście o Hitlerze à rebours; autor ubiera je w bardzo mocne słowa, przejmując całe nazistowskie frazy, które wypowiada pod adresem plażujących rodaków: „Ale mam za to dobry indeks cefaliczny! Zmierzcie sobie w domu głowy! [...] Szydło z worka wyjdzie, raso niedomyta!"36. Zachowując militarny styl i treść przekazu, mówi też o nich samych tak:

Widzę: dużo ludzi starych, wloką za sobą mozolnie worki swoich ciał, tak powiem. Postuluję: zabronić im wstępu na plażę. Powód: kapitulacja ciała przed wrogiem czasu. A czas: wymyślili Żydzi, wiadomo. Sam się przecież nie wymyślił.

Propozycja pierwsza, którą nazwę rozbrajającą: puścić ich na plażę, na której mogą jeszcze znajdować się bomby, niech je, drepcząc tam i z powrotem, rozbrajają?

Skrzydlate słowa i skrzydlate miejsca wytwarzają przestrzeń, w której można wziąć symboliczny odwet, naprędce zmontować z obrazów i słów amalgamatową kontrę przeciw germanizacji i okupacji. Można też zawsze jeszcze ponieść, zdaje się twierdzić Rudnicki, typowo polską, przesyconą polszczyzną ofiarę: "Chmary dzieci z wiaderkami do nieba czwórkami by szły"38. Narracja prowadzona jest przy tym tak, by pokazać mechanizmy brania odwetu. Autora interesuje jednak nie tyle sam odwet, co właśnie sposoby jego powstawania i możliwego eskalowania. Nie jest to może mechanizm bardzo skomplikowany, ale z pewnością wymaga wyczulenia na język. Rudnickiemu wystarczy jakieś skojarzenie, językowy haczyk, a wyobraźnia zerwana $z$ łańcucha poprawności politycznej... zostaje na łańcuchu historii. Podobne skojarzenia, czasem lepsze językowo, czasem gorsze, słychać na polskich ulicach i w mediach, by wspomnieć choćby takie hasła, jak „PO - gestapo" czy „Tusk - Hitlerek”.

\footnotetext{
35 Ibidem.

36 Ibidem.

37 Ibidem.

38 Ibidem.
} 


\section{„KSIĘŻNICZKA SCHODZI DO SCHRONU"39}

Dialogi, jakie prowadzi pisarz ze swoimi protagonistami, są w punkcie wyjścia nierówne, rzecz jasna na korzyść Rudnickiego. Prezentowane w kolejnych eseistycznych omówieniach postaci zależą bowiem tylko od niego, ponieważ to on wybiera z ich życiorysów co lepsze "kąski”. Zwykle są to, można powiedzieć, fragmenty bardzo mięsiste, bezpośrednio związane z ciałami opisywanych ludzi.

W tekście Samobójstwo Frau Kohl, opartym na jej biografii ${ }^{40}$, czytamy o motywach samobójstwa żony kanclerza, do którego przywiodło ją wieloletnie fizyczne cierpienie. Janusz Rudnicki odsłania wprawdzie to, co pokazał wcześniej autor oryginału biografii, ale głównie na takich aspektach przedstawienia koncentruje swoją i naszą uwagę: "gwałt zbiorowy, po którym wyrzucili ją przez okno 'jak worek cementu'” "41, „pierwsza ciąża z komplikacjami (kręgosłup), druga też" 42 , „biorą ją do szpitala, stan katastrofalny, skóra na całym jej ciele staje się staje się ciemnoniebieska" 43 .

Zwraca uwagę to rudnickie eksponowanie cielesności, na której autor Mojego Wehrmachtu wygrywa różne tony swojej opowieści o współczesnych Niemcach, ich historii - w tym przede wszystkim o II wojnie światowej. Zanim bowiem czytelnik dowie się, że Hannelore całe dorosłe życie ciężko chorowała, pozna dzieciństwo małej księżniczki „w krainie przepychu”44. Taką niby bajkę gwarantował zaś córce ojciec Wilhelm, producent amunicji, którego „kariera rosła proporcjonalnie do ekspansji III Rzeszy na Europę. Na Polskę szczególnie [...]"45.

Wypominanie historii tej „rodziny po niemiecku” przeplata się więc pod piórem Rudnickiego z obnażaniem bohaterki, co ona sama, również pod postacią zdrad męża, tak boleśnie przeżywała. Wyraźnie i z determinacją eksponując biologiczny aspekt uczuć powiązanych z ciałem, a także plastyczność biografii uzależnionej od często traumatycznego dzieciństwa, podejmuje Rudnicki pewną grę o władzę nad swoimi bohaterami. Jeśli wziąć pod uwagę fakt, że „z doświadczeń historycznych z Niemcami pozostało 'nam', jako tym, powiedzmy, 'kolonizowanym', poczucie upokorzenia i wyższości moralnej"46, postawa pisarza nie dziwi. Wszak emocje na ogół „kształtowane są przez określone warunki kulturowe i nierówności" 47 .

39 J. Rudnicki, Samobójstwo Frau Kohl. „Książki. Magazyn do czytania” 2011, nr 3, s. 31.

${ }^{40}$ H. Schwan, Die Frau an seiner Seite. Leben und Leiden der Hannelore Kohl. Monachium 2011.

${ }^{41}$ J. Rudnicki, op. cit., s. 32.

42 Ibidem.

43 Ibidem.

${ }_{44}^{4}$ Ibidem, s. 31.

${ }^{45}$ Ibidem.

${ }^{46}$ B. Helbig-Mischewski, op. cit., s. 163.

${ }^{47}$ M. Rajtar, J. Straczuk, Wprowadzenie. W: Emocje w kulturze. Red. M. Rajtar, J. Straczuk. Warszawa 2012, s. 7-21. 
Równolegle jednak tymi tekstami emotywnie komunikuje nam, jak znaczące, ale i niejednoznaczne napięcie między winą a wstydem cechuje współczesnych Niemców. W afekcie Rudnickiego rozpoznaję też wreszcie świadectwo uznania i poszanowania godności tragicznych postaci, które bierze na warsztat. One też podlegały własnej kolonizacji i zasługują na status pokrzywdzonego.

\section{„KRÓL JEGO WYSOKOŚĆ ŚWIR Z BERŁEM W DŁONI W POSTACI PENISA" 48}

Jeszcze ostrzejsze działo winy pomieszanej ze wstydem wytacza Rudnicki w eseju Jak kształtowata się rodzina Krupp, poświęconym dziejom rodu potentatów stalowych, którzy „ubrali Hitlera na wojnę”. By uatrakcyjnić odrysowywaną tu z dwóch nużących go źródeł ${ }^{49}$ długą i szczegółową historię niemieckiej familii, wzbogaca tekst o stosowne dla polskiego odbiorcy rymy: "Jego słowa [Hitlera] trafiały do ludzi, ich armaty z Essen w ludzi. [...] 'Krupp' rymuje się z 'trup'"50. Rymowanki kojarzą się z dziecięcą zabawą, igraszkami i te również żywo zajmują autora, który za cel bierze sobie ostatniego z dynastii Kruppów:

Urządzał bizantyjskie orgie, brał narkotyki. Mieszkał w Marrakeszu, uwielbiał Afrykę, odbiła mu palma, inscenizował biesiady teatralne w swoich zamkach, podczas których zasiadał na tronie i kazał się tytułować.

Król Jego Wysokość Świr z berłem w dłoni w postaci penisa. I fobie, i histerie, i samotność ${ }^{1}$.

Nośne jest więc dlań to, co świadczy o pewnej, w potocznym rozumieniu, słabości opisywanych postaci i jest ważnym rysem ich, by tak rzec, „niemieckiej”, ale też prywatnej biografii (przyjaźń Kruppów z Hitlerem i domowe piekło). Poznajemy zatem bliżej grupę osób powszechnie w Niemczech znanych, ale słabych w swoim człowieczeństwie, ważnych, ale strasznych i dziwacznych, pokrzywdzonych a odsłoniętych $w$ jakimś bardzo wstydliwym dla nich aspekcie (choroba, natręctwo, tzw. inność). Autor formuje z nich rodzaj zastępu przybocznych, by przy ich udziale spotkać Polskę z takimi właśnie Niemcami. Dlatego, na przykład, zajadły antysemityzm Wagnera zderzony zostaje z jego osobistymi dziwactwami, chorobami nerwów i ciała. Tak jak Arndt von Bohlen und Halbach prowadził swoje ekscentryczne życie emeryta już od trzydziestego roku życia i wciąż poprawiał

\footnotetext{
48 J. Rudnicki, Jak kształtowała się rodzina Krupp. „Nowe Książki” 2013, nr 1, s. 27.

${ }^{49}$ H. James, Krupp, Deutsche Legende und globales Unternehmen. Przeł. K.-H. Siber. Monachium 2011 oraz L. Fischer, Krupp. Eine deutsche Familie. Berlin 2009.

50 J. Rudnicki, Jak ksztattowała się..., op. cit., s. 26.

51 Ibidem, s. 27.
} 
urodę, tak Ryśka niesforna ${ }^{52}$ kochał „pantalony obszyte koronką". Zaś do łóżka na noc ten "prekursor ostatecznego rozwiązania” zakładał duży beret z aksamitu.

W takiej oto armii autora Mojego Wehrmachtu dominującą strategią nawiązywania kontaktów jest wszechobecna familiaryzacja, możliwa dzięki uprzedniemu infantylizowaniu opisywanych, których łączy dramat bycia Niemcami i w ogóle ludźmi. Jeśli uwzględnić całość jego literackiej twórczości, warto dodać, że sylleptyczny bohater-narrator Rudnickiego nader często sam był zawstydzany przez Niemców. Tutaj chce zawstydzić m.in. upatrzonych sobie okrutników, pokazując ich własny bezwstyd lub bezwstydną historię rodziny. Mimo tego, że umieszcza tzw. kompromitujące fakty $\mathrm{w}$ centrum narracji, zdradza jakiś rodzaj zrozumienia, niekiedy też solidarności ze swoimi Niemcami, a w niektórych przypadkach empatii. „,...] Siły języka uruchomione w służbie ofiary mogą stać się jej największym wrogiem", ale nie tylko Polacy mają prawo do tego pierwszego statusu.

Tak jak jego kolejne tomy prozy również przywołane tu mniejsze formy to teksty wartkie i zabawne. Rudnicki jest wyznawcą tej pisarskiej zasady, że afekt to nie tylko niechęć czy sympatia, ale po prostu również śmiech. W efekcie polskoniemieckie lektury raz po raz wybuchają jak fajerwerki, emocje w tekście zaś przekładają się na emocje w odbiorze. Koronnym dowodem na to, że autor Męki kartoflanej potrafi zadbać o dodatkowe czytelnicze atrakcje, jest oprawa dźwiękowa jego tekstów: „Halo?! Słychać mnie!? Próba mikrofonu: raz, dwa, trzy, cztery, lecą helikoptery..." 53 .

Janusz Rudnicki zachowuje się jak strateg, który rozpracowuje przeciwnika, bo go poznał od wewnątrz. Żeby osiągnąć swoje cele, wykorzystuje informacje przechwycone: owe niemieckie książki, które z poziomu strategicznego, przechodzą na poziom operacyjny - służąc też wejściu w obcą kulturę. Pozostaje pytanie, jaki charakter (pokojowy, zaczepny?) ma jego misja, skoro „nawet druk trzeba ro zst r z el a ć, żeby wszystko stało się jasne" 54 .

\footnotetext{
52 J. Rudnicki, Ryśka niesforna. „Nowe Książki. Magazyn” 2013, nr 3, s. 50-53.

53 J. Rudnicki, Drogi panie..., op. cit., s. 42

54 Ibidem, s. 41.
} 